\title{
Water quality indicators in Lake Xochimilco, Mexico: zooplankton and Vibrio cholerae
}

\author{
Sarma NANDINI, Pedro RAMÍREZ GARCÍA, S.S.S. SARMA \\ Division of Research and Post-graduate Studies, National Autonomous University of Mexico Campus-Iztacala, Av. De Los Barrios \#1, \\ Los Reyes Iztacala, Tlalnepantla, State of Mexico, Mexico \\ Corresponding author: nandini@unam.mx
}

\begin{abstract}
Lake Xochimilco is a eutrophic water body in Mexico City used by the local population for aquaculture and agriculture. Water level is maintained with inputs of partially treated waste water from the Cerro de la Estrella treatment plant. In this study we analyzed the water quality at two sites of Lake Xochimilco, Lake Xaltocan and the Santa Cruz Canal using various indicators such as zooplankton diversity, saprobic indices, bacterial concentrations and physico-chemical variables. Eighty liters of water were filtered from Lake Xochimilco from each site, once a month from March to October of 2012, and the rotifers, cladocerans and copepods were enumerated and identified. Physico-chemical parameters such as temperature, $\mathrm{pH}$, Secchi depth, water depth, nitrogen and phosphorus and chlorophyll a concentrations, and bacterial densities were measured. During the study we recorded 33 species of rotifers, the most abundant being Brachionus angularis, B. calyciflorus and B. havanaensis. Among the microcrustaceans the most abundant were the cladoceran Moina micrura and the copepods Acanthocyclops americanus and Arctodiaptomus dorsalis. The species diversity was around 2 bits/ind. and the saprobic index between 1.5-2.0, indicating that both sites were $\beta$ meso-saprobic. At both sites nitrogen was $<1 \mathrm{mg} / L$ and phosphorus ranged between $2.5-7.8 \mathrm{mg} / \mathrm{L}$. Chlorophyll a concentrations were between $66-136 \mu \mathrm{g} / \mathrm{L}$. The toxigenic (Vibrio cholerae NoO1/No-O139) and the non-toxigenic (Vibrio cholerae No-O135) strains of the bacterium were recorded, closely associated with littoral rotifers and cladocerans particularly Brachionus quadridentatus and Alona sp. All variables indicate that these sites in Lake Xochimilco are eutrophic and highly contaminated and that the water quality needs to be improved.
\end{abstract}

Key words: Rotifers; microcrustaceans; saprobic index; Vibrio cholerae; water quality.

Received: March 2015. Accepted: August 2015.

\section{INTRODUCTION}

Lake Xochimilco is a system of relict channels of large, shallow, ancient lakes, over which the Aztecs built their city of Tenochtitlan and were transformed by the chinamperas agricultural practices which includes building of floating islands for agriculture (United Nations-CSDWAND, 2006). This system is eutrophic and often polysaprobic, thus affecting sensitive species and allowing only resistant taxa to persist. Its channels cover an area of $125 \mathrm{~km}^{2}$. One of the major problems is the poor treatment of the water in the feeding channels and part of the agricultural area. Most of it comes from the Cerro de la Estrella waste water treatment plant, which for decades, has filled the lake area. This water body also contains several pathogens and is often the focal point for several hydrotransmissible diseases, including cholera (Rodríguez-Angeles, 2002). Unfortunately, the agricultural system on the lake, regardless of the poor water quality, currently provides vegetables to Mexico City. Previous works showed the epidemiological distribution of different serotypes and serogroups of pathogenic E. coli and V. cholerae non- 01 (Solís, 2005).

Survival of pathogenic bacteria in aquatic environ- ments is affected by biotic and abiotic factors such as zooplankton bacterivory, oxygen concentrations, $\mathrm{pH}$, temperature, conductivity and availability of nutrients (Cortés et al., 2000; Joaquim-Justo et al., 2006). The importance of zooplankton in the energy transfer to higher trophic levels has been well documented (Nandini et al., 2004). Cladocerans, copepods and rotifers $(40-500 \mu \mathrm{m})$ are important generalist or specialist feeders, depending on the species (Gulati et al., 1990). Zooplankton are important for the development and spread of $V$. cholerae (Huq, 1983). Microcrustaceans such as cladocerans and copepods are particularly important since several studies show that $V$. cholerae (Huq, 1983, 1996; Borroto, 1997) adheres to the animals using the chitinous carapace as a source of nutrients to be degraded by chitinase (Lipp et al., 2002).

Lake Xochimilco has high densities of tilapias and carps, which makes the predation pressure on microcrustaceans high; it is also populated by the endemic and endangered Axolotls (Ambystoma mexicanum). The zooplankton is often dominated by rotifers, as in many tropical water bodies, due to the high predation pressure on microcrustaceans by fish larvae. The lake also has moderate densities and diversity of microcrustaceans (Nandini et al., 
2005, 2007; Enriquez-Garcia et al., 2009). Zooplankters are sensitive indicators of water quality and several indices have been developed using them (Sládecek, 1983). A commonly used one is the saprobic index which indicates the load of putrescible organic matter in surface waters and their decomposition. Levels of decomposition are also reliably estimated by evaluating the BOD levels. Previous studies in Xochimilco indicate that it has a high level of decomposition; the BOD values were often above 10 and up to $80 \mathrm{mgL}^{-1}$ (Nandini et al., 2005). Rotifers, cladocerans and copepods are often efficient bacterivores and are capable of lowering bacterial concentrations in partially treated waste waters (Monakov, 2003; Nandini et al., 2005). Some taxa such as the cladoceran Moina macrocopa and the rotifer Brachionus rubens, in fact have higher population growth rates on partially treated waste water with high levels of decomposing organic wastes as compared to defined cultured media with algal food (Nandini et al., 2004). Considered as generalist, Moina species are unable to select specific food quality based on taste or nutritional quality. Ramírez-García et al. (2012) report that rotifers do not feed on $V$. cholera as much as cladocerans. The implication of this in relation to the zooplankton of Lake Xochimilco has rarely been analyzed, in spite of the importance of lowering densities of this pathogenic bacterium by all possible means.

The increasing demand for freshwater for drinking water production and agriculture emphasizes the importance of research on water quality. From the clinical point of view, studies on Vibrio cholerae in Lake Xochimilco are also very important because vegetables irrigated with water from this lake are widely consumed in Mexico City. Therefore, the objectives of this study were to analyze the zooplankton in relation of Vibrio cholerae and water quality variables in two sites in Lake Xochimilco over a period of eight months.

\section{METHODS}

Monthly samples were collected at two sites in Lake Xochimilco, the canal Santa Cruz and the lake Xaltocan (Sites I and II, respectively) from March to October, 2012, a period that includes the dry and the rainy season in Mexico City. We collected the zooplankton samples, filtering $80 \mathrm{~L}$ of water through $63 \mu \mathrm{m}$ plankton net (the effective pore size was much lower due to the accumulation of seston from the lake on the mesh during the process of filtering) and fixing the samples immediately in the field with $4 \%$ formalin. Moore swabs were set up at each site in order to collect as many planktonic Vibrio as possible. After $24 \mathrm{~h}$, these were removed and transported to the laboratory in Amies medium and processed immediately to enumerate the bacteria.

In the laboratory, rotifers were identified using Koste (1978) and quantified using a Sedgewick Rafter counting chamber. We counted three aliquots of one milliliter from each sample, and the average of the three counts were used for further analyses. During this study all the rotifer, cladoceran and copepod species were quantified and in this process more than 1000 individuals of the dominant taxa were enumerated. We selected rotifers which reached densities more than 300 ind. $\mathrm{L}^{-1}$ at either study site during any month of the year as a dominant species and followed changes in its population density over the study period. In the case of micro-crustaceans, species present for most of the sampling period were selected for further analyses.

Physical and chemical variables such as temperature, $\mathrm{pH}$, dissolved oxygen and conductivity were measured in the field using Hanna probes and transparency was also measured using a Secchi disk. Dissolved nitrates and phosphates were measured using a YSI 9100 multi-parameter test kit and the $\mathrm{BOD}_{5}$ following Clesceri et al. (1998). Chlorophyll a was extracted using acetone and measured using a Fluorometer (Aquafluor, Turner Equipments). Bacteria were enumerated by growing $10 \mathrm{ml}$ aliquots of the sample on alkaline peptone broth, incubated at $37^{\circ} \mathrm{C}$ for $18 \mathrm{~h}$, and then the biofilm was plated on TCBS agar plates for enumerating typical colonies of Vibrio cholerae (Colwell et al., 1980;).

Zooplankton diversity was calculated using the Shannon-Wiener formula (Krebs, 1993):

$$
H^{\prime}=-\sum p_{i} \log _{2} p_{i}
$$

where $H^{\prime}$ is the index of species diversity, and $p$ is the proportion of individuals of the $i$ th species.

Species diversity was calculated using the program DIVERS as in Krebs (1993). Data were tested for statistically significant differences using $t$-tests (Sigma Plot 12 - http://www.sigmaplot.com). In order to test for relations between the physicochemical variables and Vibrio cholerae with zooplankton we conducted a multifactorial analysis using CANOCO for Windows 4.5.

Saprobic indices (S) were calculated using the formula proposed by Pantle and Buck (1955):

$$
S=\Sigma(s . h) / \Sigma h
$$

where

$S$ is the Pantle and Buck (1955) saprobic index; $s$ is the valence of each rotifer (Sladecek, 1983); $h$ is the relative frequency (1, uncommon; 3 , common; 5 , abundant);

The saprobic index $S$ is based on the following ranking scale: $1.0-1.5$, oligosaprobic; $1.6-2.5, \beta$ - mesosaprobic; 2.6-3.5, $\alpha$-mesosaprobic; $3.6 \geq 4.4$, polysaprobic.

The trophic state of the reservoir was calculated using ratios based on the number of Brachionus to Trichocerca species (B/T ratios; Sládeček, 1983). 


\section{RESULTS}

The physicochemical variables observed at both study sites during this period are shown in Tab. 1. The temperature ranged between $19.5-22^{\circ} \mathrm{C}$ with no significant differences between sites. Both sites are part of a shallow water body where the maximum depth did not surpass $1.5 \mathrm{~m}$; the Secchi transparency was also low ranging between 0.18 $0.4 \mathrm{~m}$. The conductivity was low as can be expected in a freshwater body; the $\mathrm{pH}$ ranged between 6.9-9.5 and was almost always alkaline at both sites. The COD ranged between $80-135 \mathrm{mg} / \mathrm{L}$ and was often lower in the lake as compared to the canal. The dissolved oxygen was higher $(>10 \mathrm{mg} / \mathrm{L})$ during spring and autumn as compared to the summer months at both sites. In general, the oxygen levels were lower $(<4 \mathrm{mg} / \mathrm{L})$ in the Canal as compared to the lake (Fig. 1). Both sites were severely nitrogen $(<1 \mathrm{mg} / \mathrm{L}) \mathrm{lim}$ ited as compared to phosphorus $(2.5-7.8 \mathrm{mg} / \mathrm{L}$ ) (Fig. 1). Chlorophyll a $(66-136 \mu \mathrm{g} / \mathrm{L})$, coliform bacteria and Vibrio sp. concentrations were higher in the canal as compared to the lakes (Fig. 1); overall these levels along with those of the nutrients clearly indicate that this is a highly eutrophic water body.

During this study we observed 33 species of Monogonont rotifers; bdelloids were observed but not identified and therefore not enumerated (Table 1). The most species rich family was Brachionidae. The rest of the families were represented by just a few species. Amongst predatory rotifers we only observed Asplanchna brightwellii and Dicranophorus caudatus, of which the former was more abundant with densities frequently above 50 ind./L. B. calyciflorus,
B. angularis and $B$. havanaensis were present during most of the study period at densities above $1000 \mathrm{ind} . / \mathrm{L}$, even more than the evasive Polyarthra vulgaris (Fig. 2).

At both study sites, during the study we observed four species of cladocerans and two species of copepods, Arctodiaptomus dorsalis and Acanthocyclops americanus (Tab. 2). The most abundant cladoceran was Moina micrura although its density was very low compared to those of rotifers, rarely increasing beyond 10 ind./L. Among the copepods, naupliar and copepodite stages of both species were more abundant as compared to the adult stages. However, the densities of cyclopoids were more than twice as high as that of the calanoid (Fig. 3). Females of both taxa were more abundant than the males. While rotifers were generally more abundant at site I, the micro-crustaceans were more abundant at Site II. The species diversity was above 2 bits/ind. during most of the study period, at both sites; in general it was significantly higher $(\mathrm{P}<0.01 ; t$-test $)$ at Site II as compared to Site I (Fig. 4). The evenness ranged between $0.4-0.65$, during most of the study period with no significant differences amongst the study sites ( $\mathrm{P}>0.05 ; t$-test). As expected, the Pantle and Buck saprobic index was above 1.5 but below 2.0 for most of the study period at both sites but it was significantly lower $(\mathrm{P}<0.01$; $t$-test) at Site II as compared to Site 1.

In this study, both the toxigenic (Vibrio cholerae NoO1/No-O139) and the non-toxigenic (Vibrio cholerae NoO135) strains of the bacterium were recorded. The multifactorial analyses indicated that more taxa of zooplankton are associated with low levels of contamination

Tab. 1. Physicochemical variables at the study sites in Lake Xochimilco.

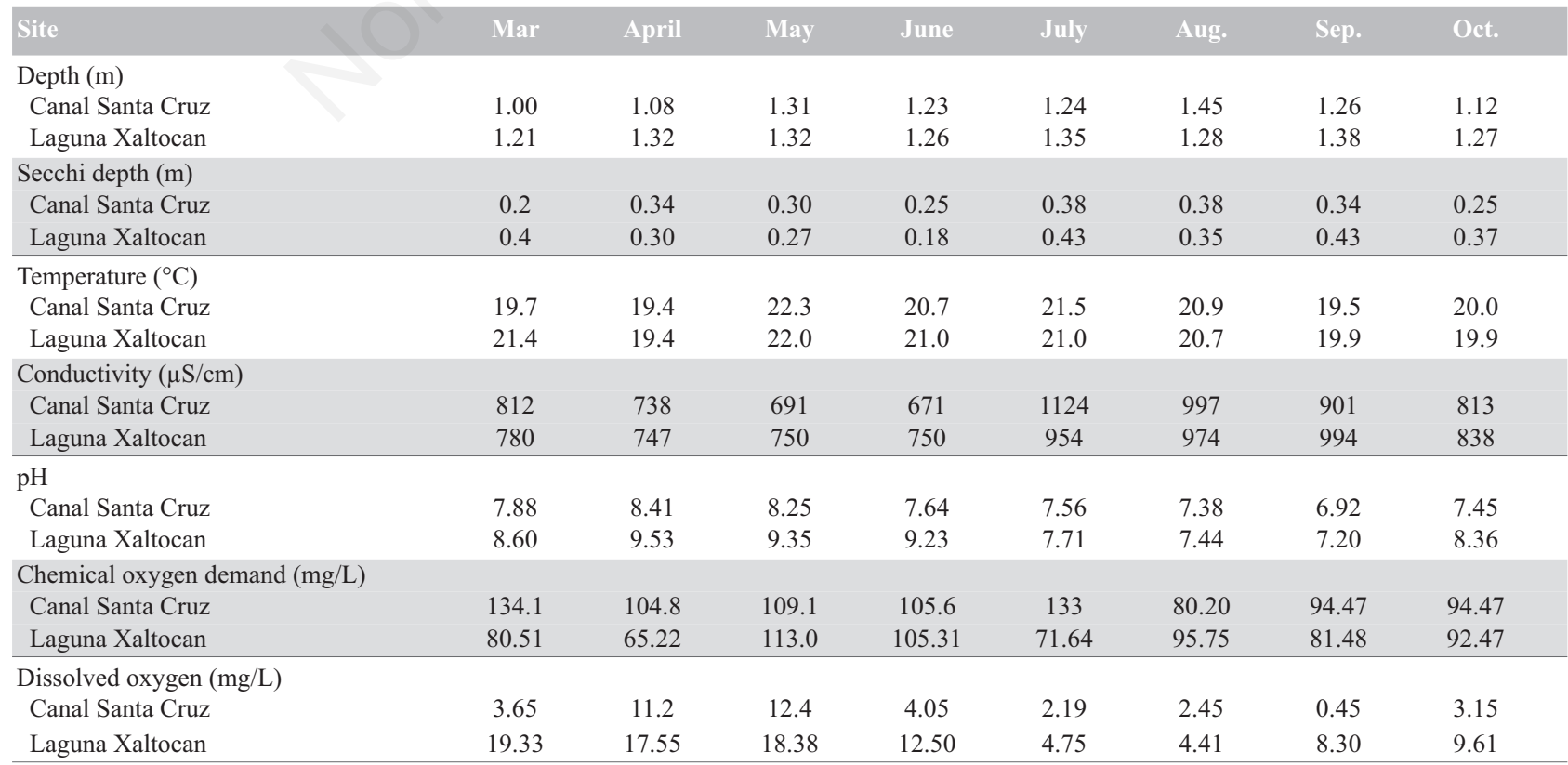




\section{SITE I}
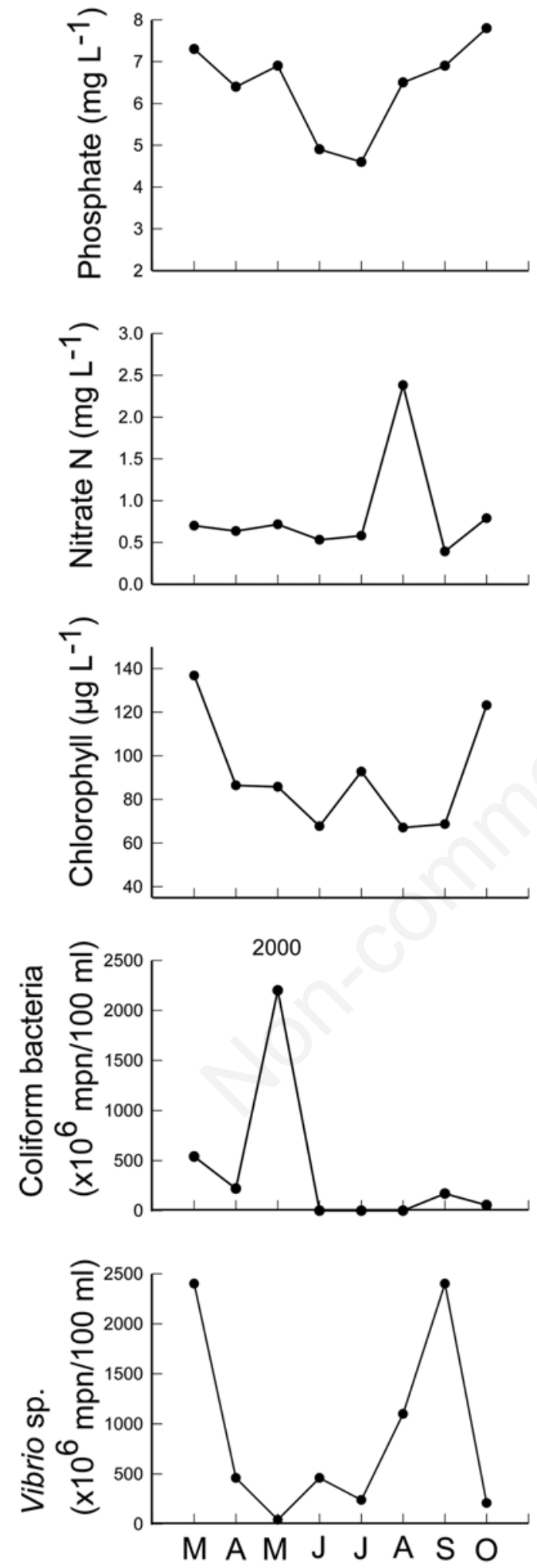

SITE II
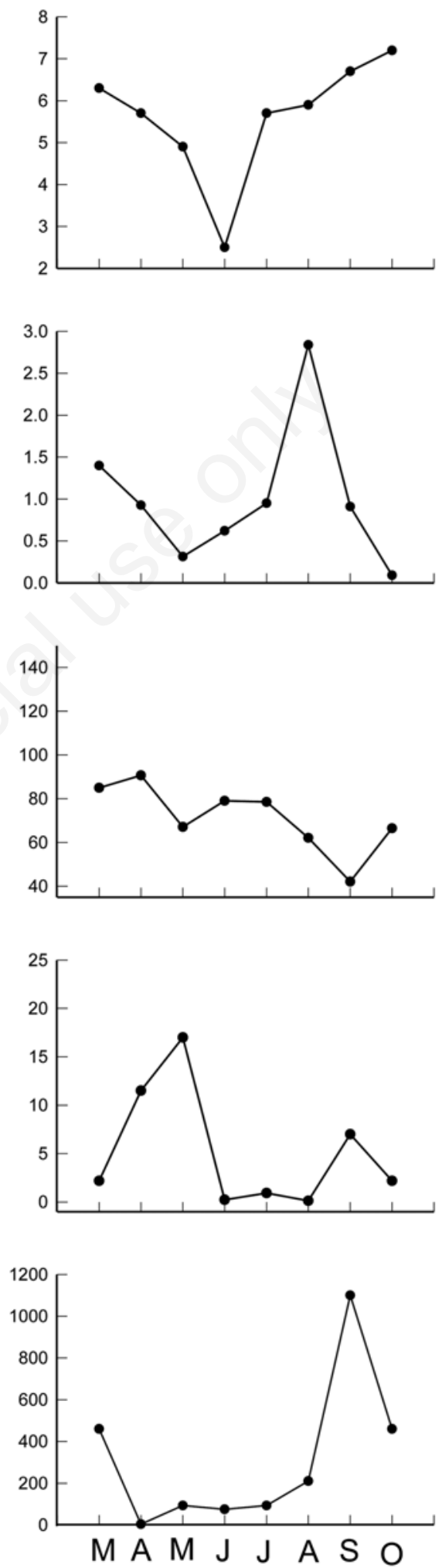

Fig. 1. Seasonal variations in the concentration of phosphate phosphorus, nitrate nitrogen, chlorophyll a, coliform bacteria and Vibrio at the two study sites in Lake Xochimilco. 
as compared to high degrees of the same (Fig. 5). Shallow waters also promote greater species richness as do high $\mathrm{pH}$ and higher concentrations of oxygen. Vibrio cholerae was closely associated with littoral rotifers and cladocerans particularly Brachionus quadridentatus and Alona sp. Most species were positively associated with high Secchi depth (less phytoplankton) and high oxygen availability or conditions of less decomposition.

\section{DISCUSSION}

Lake Xochimilco is part of the ancient lake basin that once covered the Valley of Mexico but is now restricted to small pockets in the north and south of Mexico City. This study was carried out in the southern zone of the city which has a high density of human population, thus the pressure on the water body is high. Our study clearly indicates that both the Santa Cruz canal and Lake Xaltocan
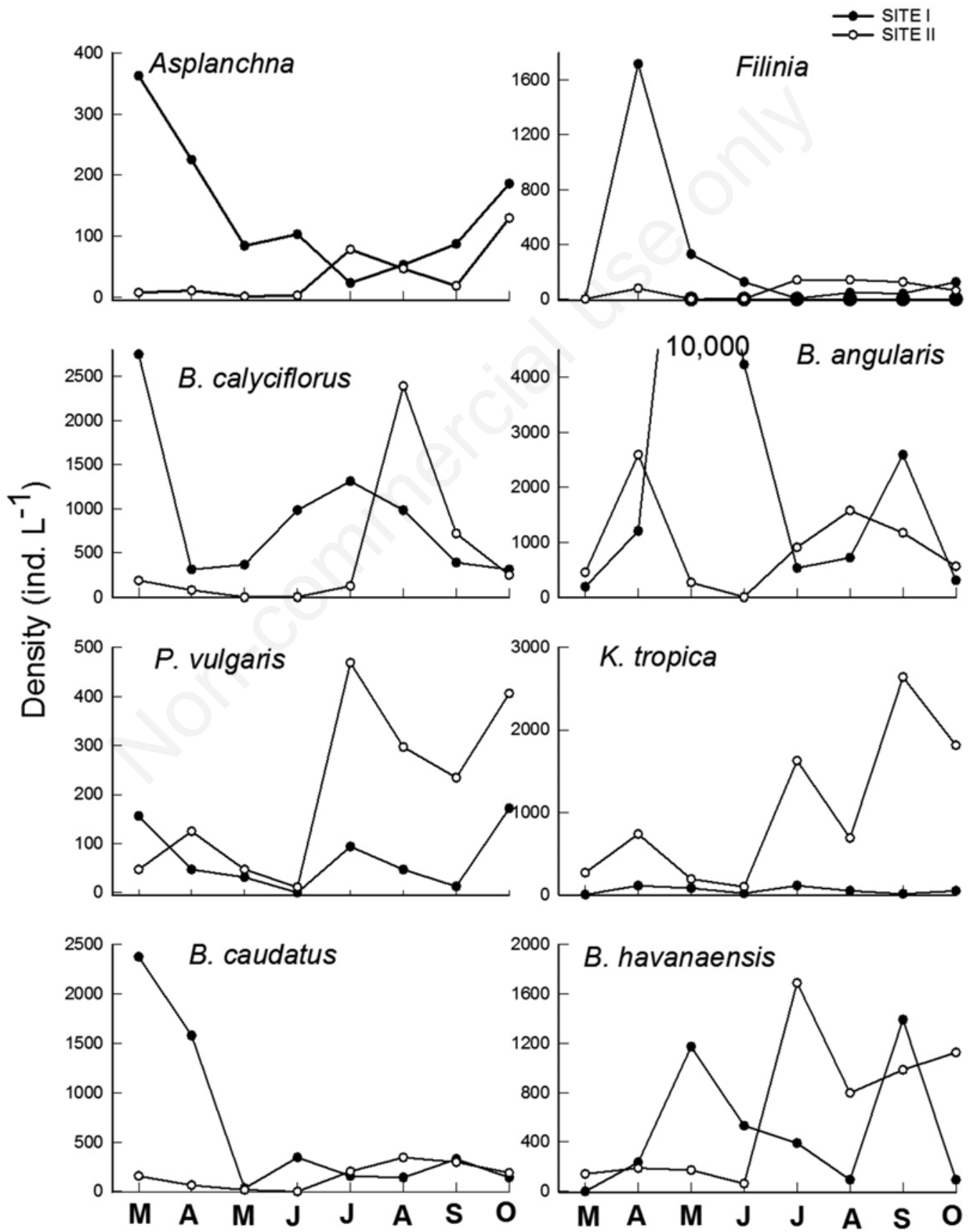

Fig. 2 Seasonal variations in the abundance of selected rotifer species from Lake Xochimilco. 
are highly eutrophic and contaminated with bacteria. The coliform bacteria concentrations observed in this work were higher than the permissible limits of $400 \mathrm{MPN} / 100$ (Clesceri et al., 1998).

Rotifers are common inhabitants of freshwater bodies and along with cladocerans and copepods form the dominant biomass of planktonic communities (Walz, 1993). Two of the factors that control the proportion of zooplankton in aquatic systems are competition and predation. Rotifers suffer from exploitative and interference competition from cladocerans which results in an inverse relationship between their densities and that of microcrustaceans (Gilbert, 1988). However, as compared to competition, predation is a stronger structuring force. The high predation pressure in Lake Xochimilco from larval tilapia and carps is well documented (Zambrano et al., 2010); these taxa reach high densities and since they reproduce all year around, they consume high numbers of cladocerans and copepods especially since the prey are more visible to these visual predators. This often results in higher densities of rotifers as compared to microcrustaceans, as observed in our study. The densities of rotifers were more than a 1000 fold as compared to the micro-crustaceans in both the Santa Cruz canal and the Lake Xaltocan; previous studies also report similar findings (Nandini et al., 2005). Among cladocerans, the only species that could be recorded on a regular basis was Moina micrura, probably because of its high reproductive rate and the copepods (Acanthocyclops americanus and Arctodiaptomus dorsalis). Copepods frequently escape predators as a result of their rapid $(80 \mathrm{~mm} / \mathrm{s})$ and evasive movements (Bradley et al., 2012).

Zooplankton species have been used as indicators of water quality in several studies in lakes and rivers (Wallace et al., 1996). Rotifers are one of the sensitive indicators but pose difficulties in acquiring adequate taxonomic skills to identify them. Nevertheless, it has been well documented that brachionids are indicators of eutrophic waters while trichocercids of oligo-mesotrophic water (Sladecek, 1983). The extremely high densities of the rotifers, often above 3000 ind./L. is also probably due to the high availability of bacteria on which most rotifers feed (Monakov, 2003). The physico-chemical variables of a low N:P ratio and high concentration of Chlorophyll a (66-136 $\mu \mathrm{g} / 1)$ are indicative of a eutrophic system (Gulati et al., 1990). Our study clearly shows that the study sites in Lake Xochimilco are eutrophic since it has a $\mathrm{B} / \mathrm{T}$ ratio of 10 , in spite of the fairly high species diversity also reported in other studies from this water body (Nandini et al., 2005; Enriquez-García et al., 2009). The saprobic index also ranged from 1.5-2.0, that is $\beta$-mesosaprobic, which shows high levels of decomposition in this aquatic system, also corroborated by the high COD. High levels of bacteria, in general and coliform bacteria in particular are also indicative of poor water quality; in Lake Xochimilco these levels are more than the maximum permissible limit since the water used to maintain the water level comes from a water treatment plant which often does not treat water to adequate levels.

Tab. 2. List of species found in the sites of Lake Xochimilco.

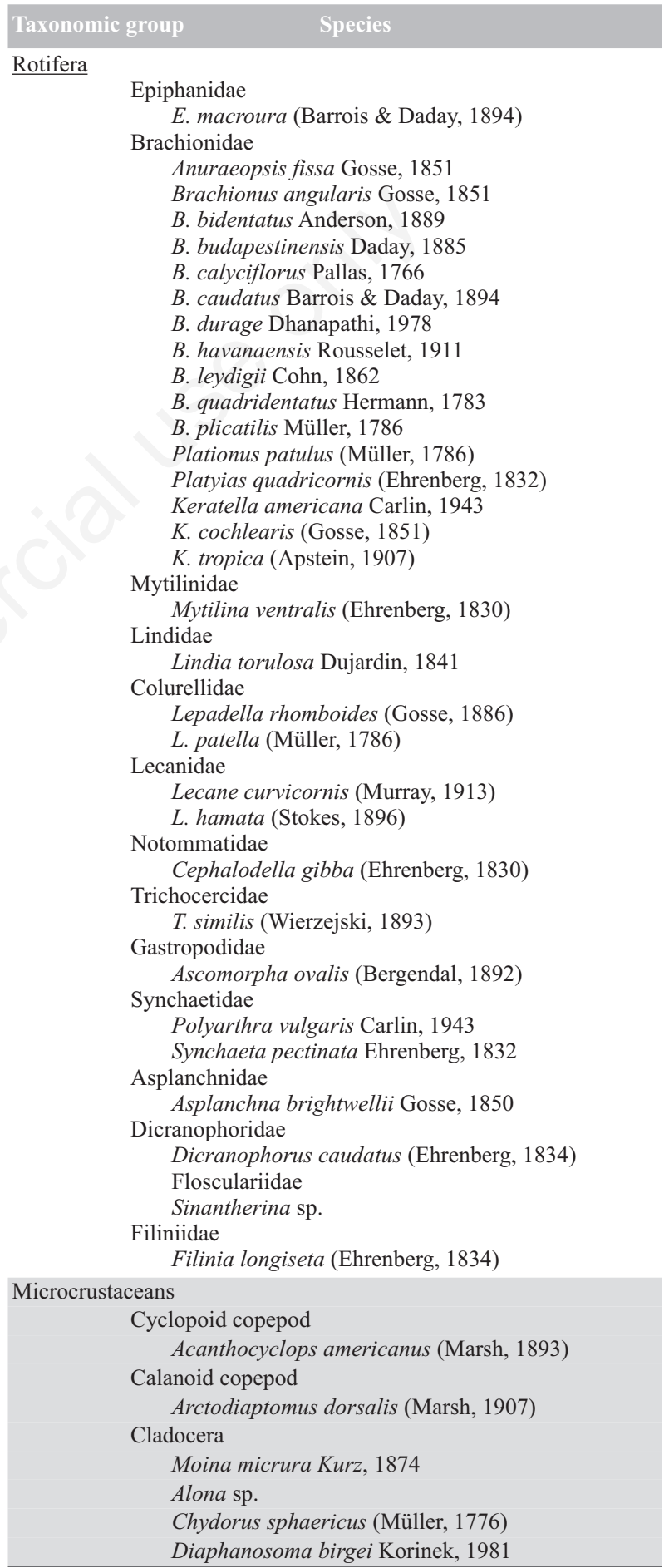


The male-female ratio in copepods is often biased towards females which is important since it results in higher population growth rates. We also found that the densities of females were higher than that of males in both Acanthocyclops robustus as well as Arctodiaptomus dorsalis. It has been suggested that this skewed sex ratio, common in both field and experimental situations, is also a result of sex change and forming intersexes that copepods are capable of (Gusmao and McKinnon, 2009).

Vibrio cholerae is frequently found in Lake Xochimilco, mostly associated with cyclopoid copepods $(64.8 \%)$, copepod nauplii $(28.9 \%)$, cladocerans $(6.3 \%)$ and the rest with rotifers. Several studies have shown that Vibrio cholerae is associated with rotifers, cladocerans and cope-
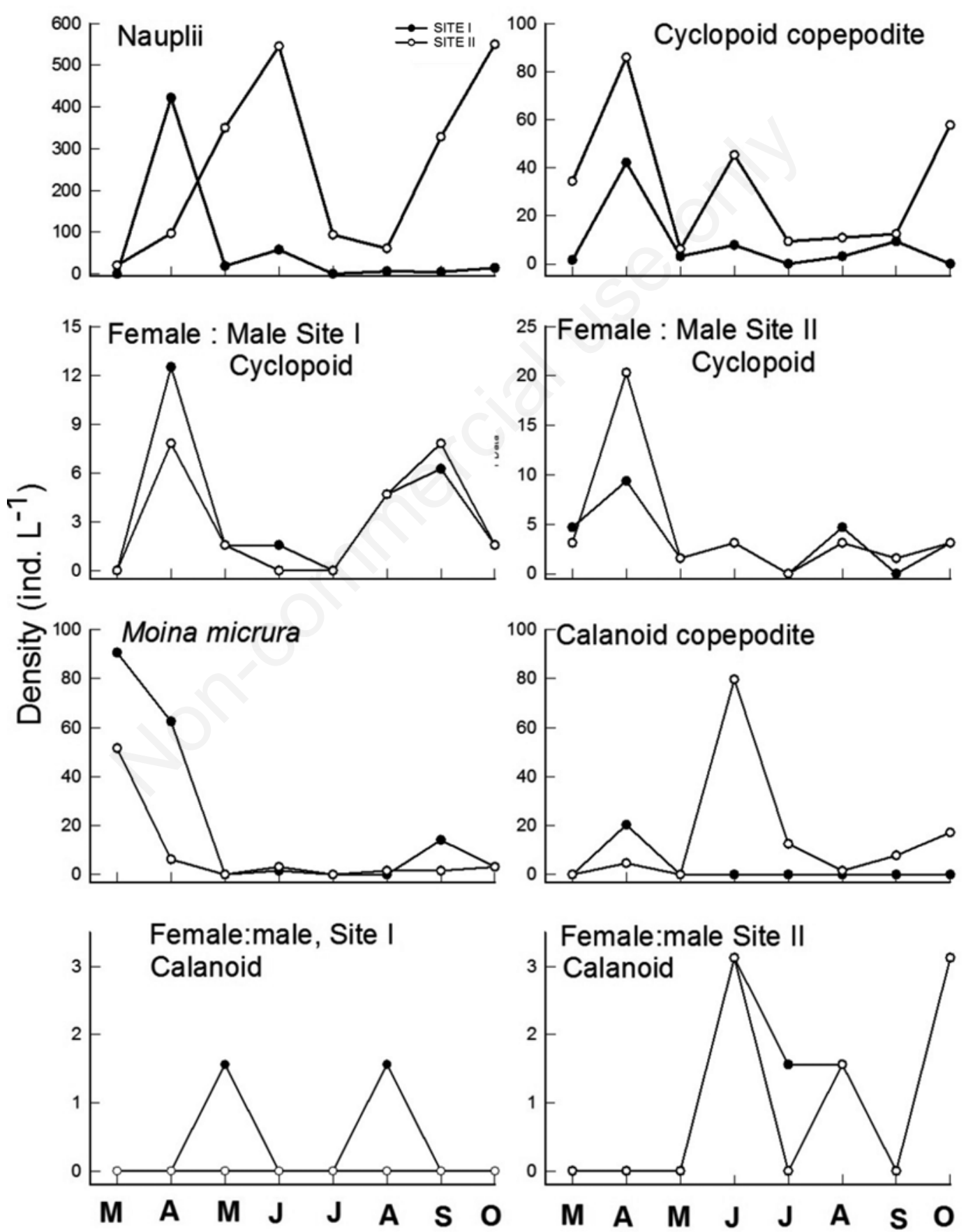

Fig. 3. Seasonal variations in the abundance of selected crustacean species from Lake Xochimilco. 
pods in fresh and brackish waters (Constantin de Magny et al., 2011). Rawlings et al. (2007) have shown that Vibrio has a propensity to be epizoic on micro-crustaceans and this helps them to cross various barriers in lakes such as the thermocline and pycnocline (Grossart et al., 2010). With total rotifer or crustaceans vs Vibrio density we found no significant correlations; however we found that Vibrio was most strongly associated with zooplankton, especially the rotifers Brachionus plicatilis, B. leydigi, $B$. quadridentatus and the cladoceran Alona. Brachionus plicatilis is frequently associated with several species of Vibrio and a new species, Vibrio rotiferianus was also
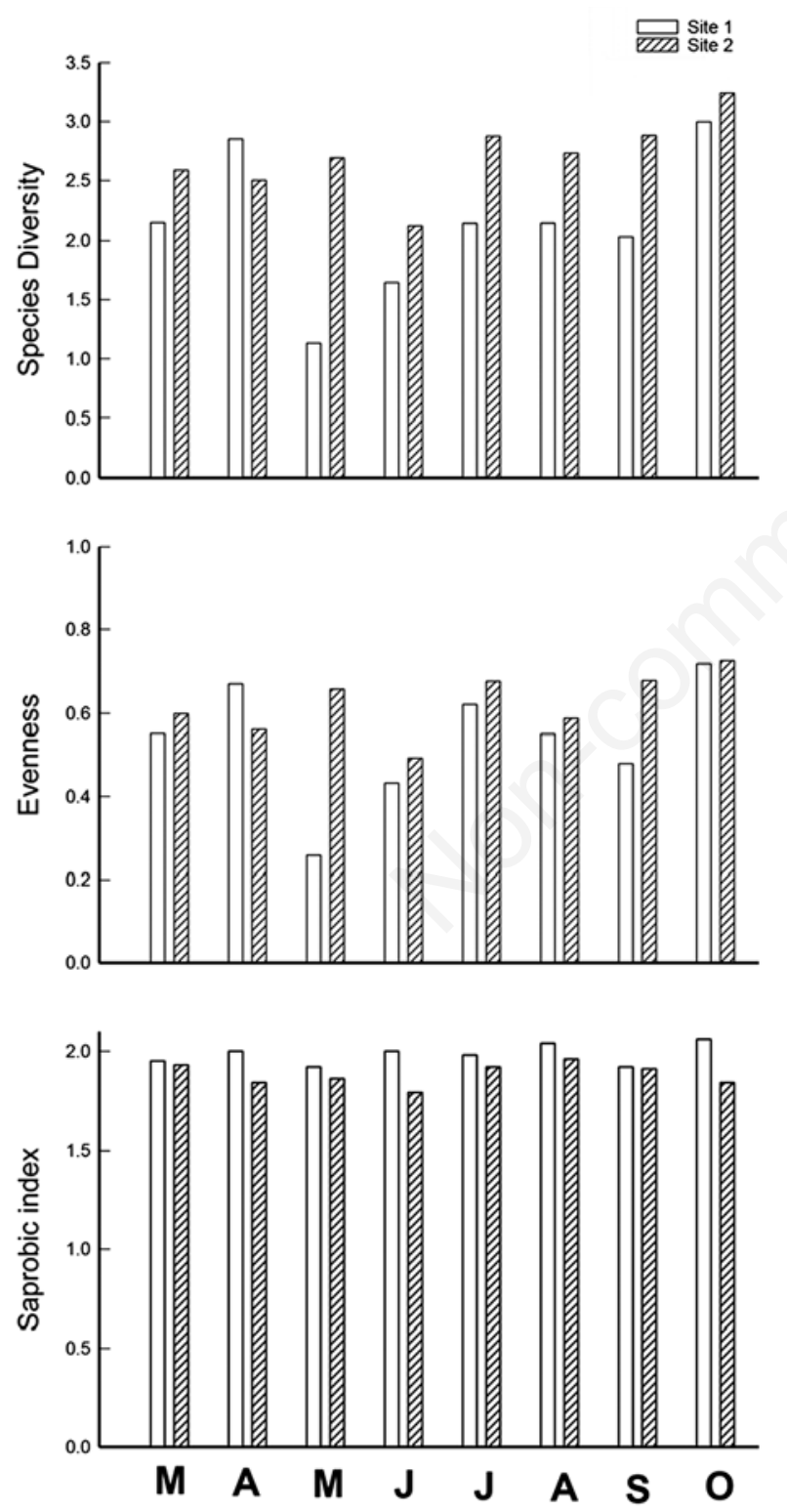

Fig. 4. Changes in the value species diversity index from the lake Xochimilco. reported on this rotifer taxa (Gomez-Gil et al., 2003). There was however no association of Brachionus angularis and $B$. havanaensis in the multivariate analyses with Vibrio although the density of these rotifers was highest during the period in which that of the bacteria was also high (Figs. 1 and 2).

Lake Xochimilco is a UNESCO Cultural Heritage Site and urgent measures are necessary to improve the water quality, especially since it is also the type locality of the endangered axolotl Ambystoma mexicanum (Zambrano et al., 2010). Our study clearly shows that both study sites are eutrophic and moderately to highly contaminated as measured by all indicators used, rotifers in the saprobic index, bacterial densities, nitrogen and phosphorus concentrations or the COD concentrations. The lake is also shallow $(<1.5 \mathrm{~m})$ and thus with a greater propensity to harbor high densities of Vibrio cholerae as shown in an extensive study by Huq et al. (2005). It is obvious that there is a health risk for the people who live in the region and use this water to fish or for agriculture. The most recommended means to improve the water quality is to improve the functioning of the water treatment plant which provides water to the lake.

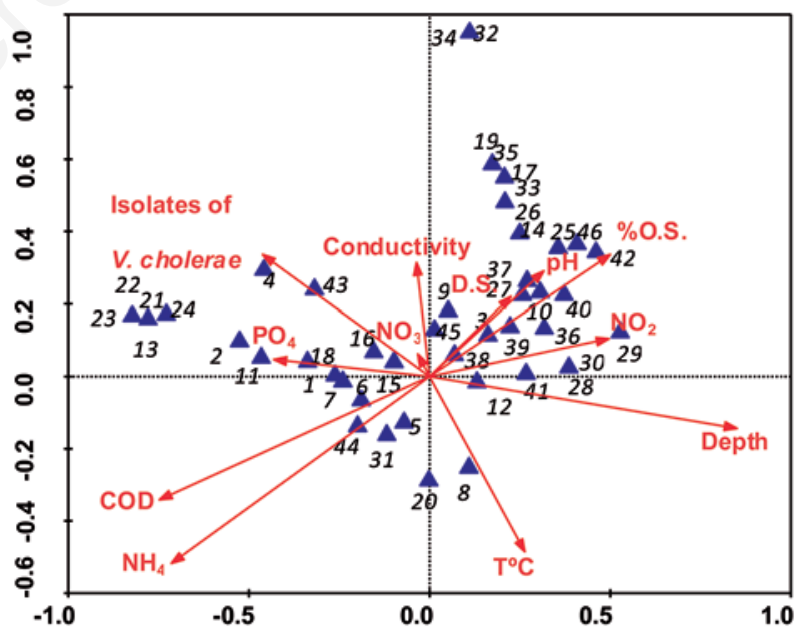

Fig. 5. Results of multifactorial analysis using CANOCO. 1, Asplanchna; 2, B. durgae; 3, Synchaeta; 4, B. quadridentatus; 5, Filinia; 6, Sinantherina; 7, B. calyciflorus; 8, B. angularis; 9, Polyarthra vulgaris; 10, K. tropica; 11, B. caudatus; 12, B. havanaensis; 13, D. caudatus; 14, T. similis; 15, B. plicatilis; 16; B. leydigi; 17, K. cochlearis; 18, B. bidentatus; 19, B. budapestinensis; 20, F. opoliensis; 21, Epiphanes macrourus; 22, Lindia torulosa; 23, L. patella; 24, M. ventralis; $25, K$. americana; 26, A. ovalis; 27, Anuraeopsis fissa; 28, L. curvicornis; 29, L. rhomboids; 30, L. hamata; 31, C. gibba; 32, Platyias quadricornis; 33, Plationus patulus; 35, Nauplii; 36, Cyclopoid copepodite; 37, Cyclopoid female; 38, Cyclopoid male; 39, Calanoid copepodite; 40, Calanoid female; 41, Calanoid male; 42, Moina micrura; 43, Alona; 44, Pleuoroxus; 45, Chydorus. 


\section{CONCLUSIONS}

Our study showed that in spite of the high levels of contamination by organic matter in the eutrophic Lake Xochimilco, as seen in the $\beta$-mesosaprobic state of the lake, the species diversity is mostly above 2 . We found both the toxigenic and the non-toxigenic strain of Vibrio cholerae (Vibrio cholerae No-O1/No-O139 and No-O135, respectively) of the bacterium in the lake. The species richness was significantly higher in the shallow part of the lake. Vibrio $\mathrm{sp}$. is closely associated with littoral rotifers and cladocerans particularly Brachionus plicatilis, B. leydigi, B. quadridentatus and the cladoceran Alona sp. This indicates a health risk for the people who live in the region and use this water for fishing or agriculture. Water quality can be improved if the functioning of the water treatment plant, which provides water to the lake, is ensured.

\section{ACKNOWLEDGMENTS}

We thank PAPCA 16 (Programa de Apoyo para Profesores de Carrera para Promover Grupos de Investigaciòn) for financial support and Martha Gaytan for technical assistance. We also thank PAPIIT (Programa de Apoyo a Proyectos de Investigación e Innovación Tecnológica) IN213413 for additional support.

\section{REFERENCES}

Borroto RJ, 1997. Ecology of Vibrio cholerae serogroup O1 in aquatic environments. Rev. Panam. Salud. Pub. 2:327-333.

Bradley CJ, Strickler JR, Buskey E J, Lenz PH, 2013. Swimming and escape behavior in two species of calanoid copepods from nauplius to adult. J. Plankton Res. 35:49-65.

Clesceri L, Greenberg A, Eaton AD, 1998. Standard methods for the examination of water and wastewater, $20^{\text {th }}$ ed. American Public Health Association.

Colwell R, Kaper R, Seider R, Voll M, McNicol L, Gargas S, Lockman H, Maneval D, Remmers E, Bradford H, Roberts N, Huq I, Huq A, 1980. Isolation of O1 and non-O1 Vibrio cholerae from estuaries and brackish water environments, pp. 44-56. Proceedings $15^{\text {th }}$ U.S.-Japan Cooperative Medical Science Program Joint Conference on Cholera. NIH publication no. 80-2003. U.S. Department of Health, Education and Welfare, Bethesda, MD, USA.

Constantin de Magny G, Mozumder PK, Grim CJ, Hasan NA, Niamul Naser M, Alam M, Bradley Sack R, Huq A, Colwell RR, 2011. Role of zooplankton diversity in Vibrio cholerae population dynamics and in the incidence of cholera in the Bangladesh Sundarbans. Appl. Environ. Microbiol. 77: 6125-6132

Cortés-Muñoz P, Ramírez-García J, Sánchez-Chávez P, 2000. Occurrence of Vibrio cholerae in the brackish water of a coastal lagoon on the Gulf of México, pp. 257-271. In: M. Munawar, S.G. Lawrence, I.F. Munawar and D.F. Malley (eds.), Aquatic ecosystems of México: status and scope. Backhuys Publ., Leiden, The Netherlands.

Enríquez-García C, Nandini S, Sarma SSS, 2009. Seasonal dynamics of zooplankton in Lake Huetzalin, Xochimilco
(Mexico City, Mexico). Limnologica 39:283-291.

Gilbert JJ, 1988. Suppression of rotifer populations by Daphnia: A review of the evidence, the mechanisms, and the effects on zooplankton community structure. Limnol. Oceanogr. 33:1286-1303.

Gomez-Gil B, Thompson FL, Thompson CC, Swings J, 2003. Vibrio rotiferianus sp. nov., isolated from cultures of the rotifer Brachionus plicatilis. Int. J. Syst. Evol. Microbiol. 53:239-243.

Grossart HP, Dziallasa C, Leunerta F, Tang, KW, 2010. Bacteria dispersal by hitchhiking on zooplankton. P. Natl. Acad. Sci. USA 107:11959-11964.

Gulati RD, Lammens EHRR, Meijer ML, Van Donk E, 1990. Biomanipulation tool for water management. Springer, Dordrecht: $628 \mathrm{pp}$.

Gusmão LFM, McKinnon AD, 2009. Sex ratios, intersexuality and sex change in copepods. J. Plankton Res. 31:1101-1117.

Huq A, Colwell RR, 1996. Environmental factors associated with emergence of disease with special reference to cholera. Eastern Mediter. Health J. 2:37-45.

Huq A, Sack RB, Nizam A, Longini IM, Nair GB, Ali A, Morris JG Jr, Huda Khan MN, Siddique AK, Yunus M, Albert MJ, Sack DA, Colwell RR. 2005. Critical factors influencing the occurrence of Vibrio cholerae in the environment of Bangladesh. Appl. Environ. Microbiol. 71:4645-4654.

Joaquim-Justo C, Pirlot S, Viroux L, 2006. Trophic links in the lowland River Meuse (Belgium): assessing the role of bacteria and protozoans in planktonic food webs. J. Plankton Res. 28:857-870.

Koste W, 1978. [Rotatoria. Die Rädertiere Mitteleuropas].[Book in German]. Borntraeger, Berlin: 673 pp.

Krebs J R, 1993. Ecological methodology. Harper Collins Publ., New York: 654 pp.

Lipp EK, Huq A, Colwell RR, 2002. Effects of global climate on infectious disease: the cholera model. Clinical Microbiol. Rev. 15:757-770.

Monakov AV, 2003. Feeding of freshwater invertebrates. Kenobi Prod., Ghent: 373 pp.

Nandini S, Aguilera-Lara D, Sarma SSS, Ramírez-García P, 2004. The ability of selected cladoceran species to utilize domestic wastewaters in Mexico City. J. Environ. Manage. 7:59-65.

Nandini S, Ramírez-García P, Sarma SSS, 2005. Seasonal variations in the species diversity of planktonic rotifers in Lake Xochimilco, Mexico. J. Freshwater Ecol. 20:287-294.

Nandini S, Enríquez-García C, Sarma, SSS, 2007. A laboratory study on the demography and competition of three species of littoral cladocerans from Lake Huetzalin, Xochimilco, Mexico. Aq. Ecol. 41:547-556.

Pantle R, Buck H, 1955. [Die biologische Überwachung der Gewässer und die Darstellung der Ergebnisse].[Article in German]. GWF-Wasser/Abwasser 96:604-620.

Ramírez-García P, Tovar A, Nandini S, Sarma SSS, 2012. Filtering rates and functional response of selected zooplankton on the bacterium Vibrio cholerae Non O1 Non O139. Tec. Ciencias Agua 3:69-76.

Rodríguez-Angeles G, 2002. [Principales características y diagnóstico de los grupos patógenos de Escherichia coli].[Article in Spanish]. Salud Pub. Mex. 44:464-475.

Rawlings TK, Ruiz GM, Colwell RR, 2007. Association of Vib- 
rio cholera $\mathrm{O} 1 \mathrm{El}$ Tor and $\mathrm{O} 139$ Bengal with the copepods Acartia tonsa and Eurytemora affinis. Appl. Environ. Microbiol. 73:7926-7933.

Sládecek V, 1983. Rotifers as indicators of water quality. Hydrobiologia 100:169-201.

Solís S G A, 2005. [Aislamiento y caracterización de Vibrio cholerae de los canales de Xochimilco].[PhD Thesis in Spanish]. UNAM / FES-Iztacala, México.

United Nations-CSD-WAND, 2006. Fourth World Water Forum. Available from: http://www.csdwand.net/data/sheet.asp?cn= Mexico\&fn=LA1464
Wallace RL, Snell TW, Ricci C, Nogrady T, 2006. Rotifera, Part 1: biology, ecology and systematics. SPB Academic Publ., Amsterdam: 299 pp.

Walz N, 1993. Plankton regulation dynamics. Springer-Verlag, Berlin: 308 pp.

Zambrano L, Valiente E, Vander Zanden MJ, 2010. Food web overlap among native axolotl (Ambystoma mexicanum) and two exotic fishes: carp (Cyprinus carpio) and tilapia (Oreochromis niloticus) in Xochimilco, Mexico City. Biol. Invasions 12:3061-3069. 